Page 759-777. ISBN: 978-602-6 988-75-1

Web Jurnal Online: jurnal.unmuhjember.ac.id

By: Laras Dwi Yunianingsih; Ria Angin

Performance Assessment of Country Civil Apparatures in the Institution of Business

Development in Cooperative and Msme Business Jember District

\title{
PERFORMANCE ASSESSMENT OF COUNTRY CIVIL APPARATURES IN THE INSTITUTION OF BUSINESS DEVELOPMENT IN COOPERATIVE AND MSME BUSINESS JEMBER DISTRICT
}

\author{
Laras Dwi Yuniangsih, Ria Angin \\ Universitas Muhammadiyah Jember \\ lharasdwiyuni@gmail.com, ria.angin@unmuhjember.ac.id
}

\begin{abstract}
*Coresponding Author

This study aims to describe the Performance Appraisal of the State Civil Apparatus in the Field of Institutional Development of the Cooperative and MSME Office of Jember Regency, in order to improve the performance of the performance of ASN employees. This research method, using qualitative research. Data sources were obtained from the Head of Institutional Subdivision, Business Development of Senior Civil Servants with 5 years of service, Medium Civil Servants with 3 years of service and Junior Civil Servants with 2 years of service. Data collection through interviews, collection and documentation. Analysis uses interactive model data analysis provided, Data collection, Data Reduction, Data Presentation, and Data Verification. Performance Appraisal of the State Civil Apparatus at the Cooperative and MSME Office in Jember Regency conducted an Assessment through Employee Work Targets and Employee Behavior. State Civil in the Cooperative Service especially in the Field of Safety and Business Development. (1) Service orientation, employees in the work safety unit supported in the good category and the implementation of services to the community are also very good, (2) cooperation, in the good humidity unit, (3) time discipline, time discipline in the airtight unit, cooperatives are still weak, there is still one employee who avoids problems of service and the performance of the employee itself.
\end{abstract}

Keywords: Assessment, Performance, State Civil Apparatus 
Performance Assessment of Country Civil Apparatures in the Institution of Business Development in Cooperative and Msme Business Jember District

\section{INTRODUCTION}

\subsection{Background}

Human resources is one of the most important factors that must be considered by organizations, because human resources that have good performance, will have a big influence on the success and implementation of an organization's activities. Without human resources that have good performance, it will be very difficult for an organization to achieve the goals set.

The Regional Government as the holder of responsibility is given full authority accompanied by the granting of the rights and obligations of the implementation of regional autonomy in a unified system of governance. The national employment system, Civil Servants or Civil Servants (PNS) has the most important position in the administration of government assigned to carry out performance planning.

Performance planning is the first task of performance management for employees every year. Employee performance needs to be trained in order to meet the expectations of an organization. Performance planning is a meeting between the valued appraise and appraisor appraisers.

Furthermore, the task undertaken by the assessor is carrying out an assessment of a vision, mission, values and objectives in each field of work, so that the performance planning process carried out by employees can take place properly and correctly, before performance planning is carried out. After that, the appraiser prepares an annual performance plan and looks at what competencies are needed by the employee to carry out his work plan. The appraiser must understand the work of the employees in his subordinates and develop it if the work no longer matches the work plan in the field or organization. After that, the assessor must divide the work objectives into the targets of his subordinate employees, then the assessor starts to assess the extent to which the competencies achieved by each subordinate to carry out their duties.

The flow of performance is the elements in the work that shows performance. To measure performance, the performance flow is developed into a unit of performance indicators as an instrument to measure the performance of an employee. The flow of performance can be divided into three types, namely: work output, is the work output in the form of goods and services that can be calculated and measured by how much the quality and quantity. Work behavior is the result of employee behavior that has to do with work such as hard work and friendliness to the community. Personal characteristics of employees that have to do with work are traits required in carrying out work.

The Government has established Government Regulation No. 46 of 2011 concerning Performance Evaluation of Civil Servants' Work, which replaces the Employment Implementation Evaluation List that has been in effect since January 1, 2014, which has so far only been qualitative and subjective, to be an assessment that is in accordance with clear and measurable targets through the Targets document Employee Performance. Furthermore, there is a new Law on Appraisal of State Civil Apparatuses contained in Law Number 5 of 2014 concerning Appraisal of State Civil Apparatuses, the Assessment is carried out through the process of education and training of human resources aimed at realizing human resources that have good performance. This 
regulation applies to all employees of the State Civil Apparatus. Therefore researchers interested in examining how the performance appraisal of the State Civil Apparatus in the Field of Institutions, Business Development Cooperatives and MSME Office of Jember Regency.

\subsection{Problem Formulation}

Based on the background as described above, the problem was formulated in the form of a question sentence, namely how to assess the performance of the State Civil Apparatus in the Institutional, Business Development Division of the Cooperative and UMKM Office in Jember?

\subsection{Research Objectives}

In general, this study aims to describe the performance appraisal of the State Civil Apparatus in the Institutional, Business Development Division of the Cooperative and SMEs Office of Jember Regency.

\subsection{Research Benefits}

\subsubsection{Practical Benefits}

In general, this research is useful to provide feedback to the Government of Jember Regency, regarding the performance appraisal of the State Civil Apparatus in the Institutional Field, Business Development Office of Cooperatives and SMEs in Jember Regency. This ASN performance appraisal feedback includes the results of the study. This research is expected to be a means to improve the evaluation system conducted by the Department of Cooperatives for ASN employees.

\subsubsection{Theoretical Benefits}

From a theoretical point of view, the results of this study are useful for contributing to the development of Government Science as well as assessing the performance of the State Civil Apparatus needed during the assessment process.

\subsubsection{Benefits for Researchers}

This research is useful to improve the knowledge and skills of writers in the field of research and as a means of evaluating the performance of the performance of the State Civil Apparatus with the knowledge gained during the lecture bench.

\section{LITERATURE REVIEW}

\subsection{Concepts of Performance Appraisal}

Performance appraisal according to Gary Dessler (2010: 322) is evaluating the current and/or past performance of employees which is very relative to their performance standards. According to Anwar Prabu Mangkunegara (2000: 67) work results in quality and quantity achieved by an employee in carrying out their duties in accordance with the responsibilities given to him. 
By: Laras Dwi Yunianingsih; Ria Angin

Performance Assessment of Country Civil Apparatures in the Institution of Business

Development in Cooperative and Msme Business Jember District

\subsection{Concept of Performance}

Performance or better known as performance is the work that can be achieved by a person or group of people in an organization, in accordance with their respective authorities and responsibilities, in order to achieve the organization's objectives legally, not breaking the law and in accordance with morals and ethics.

Hasibuan (2008: 94) states that performance is a result of work achieved by a person in carrying out the tasks assigned to him based on skill, experience and sincerity as well as time.

Pursuant to Law No. 5 of 2014 concerning Performance Assessment Article 75 that the performance assessment of civil servants aims to guarantee the objectivity of civil servant coaching based on achievement systems and career systems.

In article 76 paragraph (1): Performance appraisal of civil servants is based on performance planning at the individual and unit or organizational level, taking into account: (1) Employee Work Targets, (2) Civil Servant Work Behavior includes: (a) Service orientation, (b ) Discipline, (c) Cooperation.

The provisions of the above study, especially the State Civil Apparatus in performance appraisal, are contained in Article 75, which is about the performance appraisal of the State Civil Apparatus in the Cooperative and UMKM Office of Jemeber Regency, which is based on performance planning at the individual and group level, but researchers only focus on evaluating individual performance in the Field Institution of Business Development Cooperative and UMKM Office in Jember Regency.

\subsection{State Civil Apparatus (ASN)}

Law of the Republic of Indonesia Number 5 of 2014 concerning State Civil Apparatus explains that the State Civil Apparatus, hereinafter abbreviated as ASN, is a profession for civil servants and government employees with work agreements and work for government agencies. State Civil Servants, hereinafter referred to as ASN, are civil servants and government employees with an employment agreement appointed by the civil servant development officer and entrusted with duties in a government position or assigned to other state duties and are paid based on statutory regulations. Civil Servants, hereinafter abbreviated as Civil Servants are Indonesian citizens who fulfill certain conditions, are appointed as Permanent Civil Servants by civil servant development officials to occupy government positions. Government Employees with Work Agreements, hereinafter referred to as PPPK, are Indonesian citizens who meet certain conditions and are appointed based on work agreements for a certain period in order to carry out governmental duties.

\subsection{Mechanisms for Reporting Employee Performance of the Jember Regency Cooperative Office.}

Appraisers in the Institutional, Business Development and Cooperative Fields have Duties and Functions including: (1) Carrying out monitoring and controlling the running of ASN employees in the Institutional, Business Development Sector. (2) Carry out coordination of job duties for ASN employees in the Institutional, Business 
Development Fields listed in the Employee Work Targets. (3) Carry out an assessment of ASN employees in the Field of Institutions, Business Development based on the results of work targets implemented and employee work behavior. (4) Reporting the results of the Assessment to the Field of Personnel and HR Development in the Office of Kopeasi.

Furthermore, the HR Supervision and Development Sector has duties and functions including: (1) Carrying out supervision and development of HR for all Sectors in the Cooperative Office. (2) Carry out supervision and control of the course of each Cooperative Sector. (3) Carry out monitoring of the development of each Cooperative Sector in the context of determining coaching policies. (4) Carry out the task of empowering Cooperative Human Resources in each Sector (5) Compiling reports of responsibility for carrying out tasks in accordance with their fields and collecting assessment results files to the Planning Subdivision and sending them to the Regional Personnel Agency (BKD). The Regional Personnel Agency has the main task of assisting the Regent in formulating policies, implementing coordination, planning and implementing the authority of the district government in the areas of improving employee performance and welfare, procurement, formation, transfer and management of employee data as well as organizing education and training for employees in the context of increasing human resources good government apparatus and other tasks given by the Regent.

\section{RESEARCH METHOD}

\subsection{Type of Research}

This type of research is qualitative research. This qualitative research is a research that aims to understand various phenomena about what is experienced by employees of the State Civil Apparatus in the Field of Business Development Institutions of the Cooperative and UMKM Office of Jember Regency, by means of description and in the form of words, language in a special natural context and by making use of natural methods.

\subsection{Research Location and Time}

To find out the location of the research carried out, as it is known that based on the title of this research proposal, the research location will be in the Institutional Field, Business Development Cooperatives and UMKM Office of Jember Regency, East Java Province, Indonesia.

\subsection{Data Sources}

In this study the selected data sources are as follows: The type of data used is primary data that is data obtained from the original source directly containing data information. Primary data were obtained directly from 4 informants consisting of: (1) Head of Institutional Subdivision, (2) Senior civil servants with 5 years of service, (3) Medium civil servants with 3 years of service, (4) Junior PNS employees with working period of 2 years. While secondary data is additional data obtained from various sources 
indirectly related to research, obtained from statutory documents, journals and archives that are closely related to the problem under study.

\subsection{Data Collection Techniques}

Data collection techniques in accordance with the problems faced by this problem are carried out in the form of data collection techniques, namely: The data collection techniques of this study are as follows:

1. Observation is an effort to obtain and collect data that is done by direct observation in the field and see an object of research, in order to obtain information that has something to do with the research conducted.

2. Interview is collecting data by conducting question and answer directly to informants related to research to obtain various information directly from the source.

3. Documentation is the result of which is carried out by collecting data and collecting documents, both written documents, images and electronic media related to data retrieval.

\subsection{Methods for Determining Informants}

Determination of informants is to use Purposive Sampling or conditional samples where researchers find their research informants themselves. Informant is a person who becomes a source of data in research or a person who provides information to researchers to find answers to problems. The informant is used as an informal object for researchers to find out about the Performance of the State Civil Apparatus in the Institutional Field, Business Development of the Jember Cooperative Office of UMKM. The informants of this study are as follows:

1. Appraisal Officer (Yudho Winarto)

2. Senior employee (Rini Handayani S, SH) with a term of 5 years.

3. Middle employee (Yuli Nurul Mirawati, SE) with a term of 3 years.

4. Junior employee (Gustafia Cahya Kusuma, A. MD) with a work period of 2 years.

\subsection{Data Analysis Methods}

In qualitative research, data is obtained from various sources, using various data collection techniques, and carried out continuously until the data is saturated. So that the data analysis technique used has no clear pattern. Qualitative data analysis, Bogdan (in Sugiyono, 2017: 244) states that data analysis is a process by systematically searching and compiling data obtained from interviews, field notes, and other materials, so that it can be easily understood, and his findings can be shared with others. This data analysis is done by grouping data, breaking down into each units, synthesizing, arranging into patterns, choosing what is important and what will be studied, and then making conclusions, so that it is easily understood by oneself or others. 
By: Laras Dwi Yunianingsih; Ria Angin

Performance Assessment of Country Civil Apparatures in the Institution of Business Development in Cooperative and Msme Business Jember District

\subsection{Data Validity}

Test the validity of the data in research is often only emphasized on the validity and reliability test. In qualitative research, findings or data can be declared valid if there is no difference between what the researcher reports and what actually happens to the object under study. Triangulation is the most commonly used method of guaranteeing the validity of data in qualitative research. Trianggulation is a technique for checking the validity of data by utilizing something other than the data for the purposes of checking the data or as a comparison of the data.

\section{DISCUSSION}

\subsection{General Overview of Jember Regency}

Pursuant to Law No.12 / 1950 concerning District Government in East Java, the establishment of Regency Regions within the environment of East Java Province (with Regional Regulations), among others, the District of Jember is determined to be the Regency of Jember, based on Government Regulation Number 14 of 1976 April 19, 1976, the Jember City Region was formed with the arrangement of new territories as follows:

1. The Kemberatan Jember was abolished, and three new sub-districts were formed, one each Sumbersari, Patrang and Kaliwates.

2. Wirolegi District becomes Pakusari District and Mangli District becomes Sukorambi District.

Along with the establishment of the Jember Administrative City, the Jember Regional Authority was also shifted to an area divided from Jember to Arjasa with work areas covering Arjasa, Pakusari, and Sukowono which were previously included in the Kalisat District. With these changes or groupings, in the next development, administratively, Jember Regency was then divided into seven Regent Assistant Districts, one Administrative City area, and 31 Districts, with the enactment of Regional Autonomy since January 1, 2001 as demands No. 22/1999 regarding Regional Government, Jember Regency Government has arranged the institutional structure and organizational structure, including the removal of the Assistant Regent's Office which is now the District Coordinating Office.

\subsection{General Description of the Cooperative Office and Jember Regency UMKM}

The Jember Regency Cooperative and UMKM Office was formed based on Regent's Regulation No. 43 of 2016 concerning the position, organizational structure, duties and functions and work procedures of the Cooperative and UMKM Office of Jember Regency which is based on Presidential Regulation Number 98 of 2014 concerning licensing of Micro and Small and Medium Enterprises based on Law Number 20 of 2008 concerning MSMEs. The Office of Cooperatives and UMKM is part of the Government as well as special servants helping to serve the interests of the community, the Office of Cooperatives and UMKM are also demanded to be able to provide the best service for the people of Jember. The Vision of the Cooperative and UMKM Office in Jember Regency is the use of Information Technology to improve the productivity and 
quality of the performance of the Office of Cooperatives and SMEs, especially in serving the needs of the Cooperative community and SMEs. The mission of the Jember Regency Cooperative and UMKM Office is to develop information systems in cooperatives and SMEs that are communicative, informative, interactive and in the future used by the whole community, especially in the context of raising the quality of regional products to the international level.

\subsection{Performance Appraisal of Civil Servants in the Institutional Field, Business Development Cooperatives and MSME Office in Jember Regency.}

The performance appraisal of employees of the State Civil Apparatus is measured using the Employee Work Target assessment, where the assessment begins from the preparation of the targets that underlie the Annual Work Plan (RKT), with objective principles, there is a realistic comparison between targets and realization. Measured, in the sense of performance achievements that are quantitative and qualitative, there is always an evaluation of the evaluation of each employee through activities aimed at producing performance results. Employee performance is not only assessed from Employee Work Targets, but can also be assessed through their performance behavior that can be accounted for. The responsibilities given by superiors, carried out by every employee and must be carried out according to regulations and the performance carried out must have an important role in increasing the value of Employee Work Targets and good work behavior on every employee of the State Civil Apparatus.

Employee Performance Targets (SKP) are plans and performance targets that must be achieved by employees within a period of evaluation that are real and can be measured and agreed upon by employees and their superiors. Employee Work Targets are carried out in accordance with the assigned office duties.

Whereas, assessment through work behavior is a way of evaluating work behavior carried out through observations by appraisers of civil servants who are assessed, work behavior assessment can consider input from other Appraisal Officers at the same level in their respective work fields.

\subsubsection{ASN Performance Assessment is measured through Employee Work Targets}

Employee Performance Targets (SKP) are plans and performance targets that must be achieved by employees within a period of evaluation that are real and can be measured and agreed upon by employees and their superiors. Employee Work Targets are carried out in accordance with the assigned office duties.

\section{Senior employee with a term of 5 years in the Institutional Sector, Business Development towardswelcome Mrs. Rini.}

The assessment of Employee Work Targets for Ms. Rini was carried out by Mr. Yudo Minarto as an appraisal official who worked at the Jember Regency Cooperative and UMKM Office in the Institutional Sector, Business Development. Mr. Yudo has a position as head of the supervision section and also as an appraiser of every Civil Servant in the area of Business Development Institutions. There are several tasks or activities that must be achieved by Mrs. Rini as a Civil Servant. 
The first task was to carry out periodic and continuous inspection or supervision activities (Target) of the quantity that had to be achieved namely 335 cooperations, Quality 100, within 11 months, but Mrs. Rini only carried out (Realization) 330 cooperatives, 96 quality within 11 months counted a number 270.51 so that the SKP achievement value can be 90.17 .

Second, implementing responses to the public complaints service regarding problems between cooperatives and their members and cooperatives with the community (Target) the quantity that must be achieved by 110 cooperatives, (Quality) 100 within 11 months, but Realizing the quantity achieved by 105 cooperatives, quality 95 within 11 month, counted 266.45 so that the SKP achievement value obtained was 88.82 .

Third, implement reprimands to cooperatives that do not obey and not implement the statutory regulations (Target) the quantity that must be achieved by 100 cooperatives, (Quality) 100 within 10 months, but Realized the quantity achieved by cooperatives 95 , quality 95 within 10 months, counted 266.00 so that the SKP achievement value obtained was 88.67.

Fourth, typing a summons to the problematic cooperative (Target) the quantity to be achieved by 335 cooperatives, (Quality) 100 within 10 months, but the realization of the quantity achieved by 330 cooperatives, quality 96 within 10 months, accounting for 270.51 so the value SKP achievement obtained is 90.17 .

Fifth, carry out monitoring and evaluation of the development of cooperatives (Target) quantity that must be achieved 335 cooperatives, (Quality) 100 within 10 months, but Realizing the quantity achieved by cooperatives 330, quality 96 within 10 months, counted 270.51 so the value SKP achievement obtained is 90.17.

Sixth, carry out monitoring and evaluation of reporting for the ranking of cooperatives and the health assessment of Savings and Loans in the Cooperative Office with (Target) the quantity to be achieved by 150 cooperatives, (Quality) 100 within 11 months, but the Realization of the quantity achieved by 140 cooperatives, quality 97 within 11 months, totaling 266.33 so that the SKP achievement value obtained was 88.78 .

Seventh, implement Cooperative Accountability (Target) the quantity that must be achieved by 100 cooperatives, (Quality) 100 within 10 months, but the Realization of the quantity achieved by 98 cooperatives, 98 quality within 10 months, counted 272.00 so that the SKP achievement value obtained is 90.67 .

Eighth, carry out supervision and examination of institutional and savings and loan cooperatives so that employees must create and implement (Target) the quantity to be achieved 335 cooperatives, (Quality) 100 within 11 months, but Realizing the quantity achieved by 330 cooperatives, quality 96 within 11 month, counted 270.51 so that the SKP achievement value obtained was 90.17 .

Ninth, carry out monitoring, analysis, enforcement and compliance (Target) quantity that must be achieved by 335 cooperatives, (Quality) 100 within 10 months, but Realizing the quantity achieved by 330 cooperatives, quality 96 within 10 months, counted 270.51 so the SKP achievement value obtained is 90.17 .

Tenth, implement the implementation of institutional management and sanctions on cooperatives that do not carry out responsibilities and violate cooperative regulations 
(Target) the quantity to be achieved 335 cooperatives, (Quality) 100 within 10 months, but Realized the quantity achieved by 330 cooperatives, quality 96 in time 10 months, accounting for 270.51 so that the SKP achievement value obtained is 90.17.

So the assessment data above can be concluded that Rini's mother has a total value of the Employee Work Target (SKP) is 89.79 (GOOD).

\section{Middle employee with a 3-year term in the Institutional Field, Business Development for Ms. Yuli.}

Evaluation of Employee Work Targets for Ms. Yuli was carried out by Mr. Yudo Minarto as an appraisal official. Mr. Yudo has a position as head of the supervision section and also as an appraiser of every Civil Servant in the Institutional Sector, Business Development. There are several tasks or activities that must be achieved by Mrs. Yuli as a Civil Servant.

The first task, cooperative employees carry out periodic and continuous inspection or supervision activities on cooperative groups that take shelter in the Cooperative Office by determining (Target) the quantity to be achieved ie 335 cooperatives, Quality 100, within 11 months, but Mrs. Yuli only carry out (Realization ) 330 cooperatives, 97 quality within 11 months counted 271.51 so that the SKP achievement value was 90.50 .

Second, cooperative employees carry out responses to the public complaints service regarding problems between cooperatives and their members and cooperatives with the community by determining (Target) the quantity that must be achieved by 110 cooperatives, (Quality) 100 within 11 months, but Realizing the quantity achieved by 105 cooperative employees, 97 quality within 11 months, accounting for 268.45 so that the SKP achievement value obtained was 89.48 .

Third, employees of cooperatives implement reprimands to cooperatives that do not comply with and do not implement the statutory regulations (Target) the quantity that must be achieved by 125 cooperatives, (Quality) 100 within 10 months, but Realized the quantity achieved by 120 cooperatives, quality 98 within 10 a month, counted at 270.00 so the SKP achievement value obtained is 90.00 .

Fourth, cooperative employees carry out calls and warnings to cooperatives that do not or have not submitted quarterly, semiannual and annual reports with each cooperative group under the Cooperative Service (Target) quantity to be achieved by 335 cooperatives, (Quality) 100 within 10 months, but the realization of the quantity achieved by 330 cooperatives, 97 quality within 10 months, counted 271.50 so that the SKP achievement value obtained was 90.50 .

Fifth, cooperative employees carry out monitoring and evaluation of the development of cooperatives (Target) the quantity that must be achieved 335 cooperatives, (Quality) 100 within 10 months, but Realizing the quantity achieved by cooperatives 330, 97 quality within 10 months, accounting for 270.51 so the SKP achievement value obtained is 90.50 .

Sixth, cooperative employees carry out monitoring and evaluation of cooperative rating reporting and good Savings and Loans health assessment by determining (Target) 
the quantity to be achieved by 150 cooperatives, (Quality) 100 within 11 months, but Realizing the quantity achieved by 145 cooperatives, quality 97 within 11 months, accounting for 269.67 so that the SKP achievement value obtained was 89.59.

Seventh, cooperative official employees carry out the application of Cooperative Accountability (Target) the quantity that must be achieved 100 cooperatives, (Quality) 100 within 10 months, but the Realization of the quantity achieved by 98 cooperatives, 98 quality within 10 months, counted as much as 272.00 so that the value SKP achievements obtained by employees are 90.67 .

Eighth, cooperative official employees carry out institutional oversight and inspection and savings and loan efforts to each cooperative (Target) the quantity to be achieved 335 cooperatives, (Quality) 100 within 11 months, but Realized the quantity achieved by 330 cooperatives, 97 quality within 11 months , calculated as many as 271.50 so that the SKP achievement value obtained is 90.50 .

Ninth, employees of cooperative agencies carry out monitoring of each cooperative, conduct analysis, carry out action and carry out compliance with cooperative regulations in accordance with the (Target) quantity to be achieved 335 cooperatives, (Quality) 100 within 10 months, but Realizing the quantity achieved by employees are only 330 cooperatives, 97 quality within 10 months, accounting for 271.51 so the SKP achievement value obtained is 90.50 .

Tenth, cooperative employees implement the implementation of institutional management and sanctions on cooperatives that violate cooperative service regulations and cooperatives with the (Target) quantity that must be achieved by 335 cooperatives, (Quality) 100 within 10 months, but the realization of the quantity achieved by employees is 330 cooperatives , 97 quality within 10 months, all accounted for 271.51 so the SKP achievement value obtained was 90.50 .

So the assessment data obtained above can be concluded that Yuli's mother has a total value of the Employee Work Target (SKP) is 90.31 including the (GOOD) category.

\section{Junior Employee with a term of 2 years in the Institutional Field, Business Development towards Mr. Gustaf.}

The assessment of the Employee Work Target of Mr. Gustaf was carried out by Mr. Yudo Minarto as an appraisal official who worked in the Institutional, Business Development Division of the Cooperative and UMKM Office in Jember. Mr. Yudo has a position as head of the supervision section and also as an appraiser of every Civil Servant. There are several tasks or activities that must be achieved by Mr. Gustaf as a Civil Servant.

The first task is to carry out periodic and continuous inspection or supervision activities (Target) of the quantity that must be achieved namely 335 cooperatives, Quality 100, within 10 months, but Mr. Gustaf only implements (Realization) 329 cooperatives, quality 89 within 10 months counts a number of 263.2 so that the SKP achievement value gained 87.74 .

Second, implementing responses to the public complaints service regarding problems between cooperatives and their members and cooperatives with the community 
(Target) the quantity that must be achieved by 110 cooperatives, (Quality) 100 within 11 months, but the realization of the quantity achieved by 99 cooperatives, quality 89 within 11 month, counted 255.0 so that the SKP achievement value obtained was 85.00.

Third, implement a reprimand to cooperatives that do not comply with and do not implement the laws and regulations (Target) the quantity that must be achieved by 100 cooperatives, (Quality) 100 within 10 months, but Realized the quantity achieved by 93 cooperatives, quality 89 within 10 months, counted 258.0 so that the SKP achievement value obtained was 86.00 .

Fourth, implement calls and warnings to cooperatives that have not submitted quarterly and annual quarterly reports (Target) the quantity that must be achieved by 335 cooperatives, (Quality) 100 within 10 months, but Realized the quantity achieved by 329 cooperatives, quality 87 within 10 months, counted 261.2 so that the SKP achievement value obtained was 87.07 .

Fifth, carry out monitoring and evaluation of the development of cooperatives (Target) the quantity to be achieved 335 cooperatives, (Quality) 100 within 10 months, but Realizing the quantity achieved 329 cooperatives, quality 89 within 10 months, counted 263.2 so that the value SKP achievement obtained is 87.74 .

Sixth, carry out monitoring and evaluation of cooperative rating reporting and health evaluation of Savings and Loans (Target) quantity to be achieved by 150 cooperatives, (Quality) 100 within 11 months, but Realized quantity achieved by 135 cooperatives, quality 89 within 11 months, counted a number of 255.0 so that the SKP achievement value obtained is 85.00 .

Seventh, implement Cooperative Accountability (Target) quantity that must be achieved by 100 cooperatives, (Quality) 100 within 10 months, but Realized quantity achieved by 90 cooperatives, 90 quality within 10 months, counted as 256.0 so that the SKP achievement value obtained is 85.33

Eighth, carry out institutional oversight and inspection and savings and loan cooperatives (Target) quantity that must be achieved 335 cooperatives, (Quality) 100 within 11 months, but Realized quantity achieved 329 cooperatives, quality 90 within 11 months, accounting for 264, 2 so the SKP achievement value obtained is 88.07.

Ninth, implementing the implementation of institutional management and sanctions on cooperatives (Target) the quantity that must be achieved 335 cooperatives, (Quality) 100 within 10 months, but the Realization of the quantity achieved 329 cooperatives, quality 90 within 10 months, accounting for 264.2 so the SKP achievement value obtained was 88.07.

So the assessment data above can be concluded that Mr. Gustaf has a total value of the Employee Work Target (SKP) is 86.67 (GOOD).

\section{a. Quantity}

Quantity is the amount of work carried out by an employee in a given period. This can be seen from the results of employee work in the use of certain time and speed in completing tasks and responsibilities. Thus the quantity of work can be seen from the amount of work and use of time. The amount of work is the number of work tasks, can be 
done. The use of time is the amount of time spent in completing tasks and work. The researcher looked at the quantity of output targets set by employees at the Jember Regency Cooperative and UMKM Office. Based on quantity indicators, the level of employee performance results obtained from the assessment of Employee Performance Targets by carrying out tasks and targets with most assessors assigning tasks that must be carried out and in accordance with their functions in the Institutional Sector, Business Development. Quantity indicators are assessed based on sub-indicators The level of conformity of the target quantity and plan set in the SKP, the suitability of the realization of the target output or quantity produced by employees of the Jember Regency Cooperative and UMKM Office in the Employee Work Targets and the achievement of the work results of the Jember District Cooperative and UMKM employees . The quantity made by each employee in the cooperative service must be correct and accountable and obtain approval from the Head of the Cooperative and UMKM Office in Jember Regency because the quantity can answer the extent of the ability of each employee in carrying out their duties.

\section{b. Quality}

Quality is the quality of an employee's work or a physical standard that is assessed by how much the quality and timeliness of a work performed by human resources or other resources. Human resources in order to achieve the goals or objectives of the company properly and efficiently because the results of the work done or carried out by employees for their tasks can run well. Researchers see how big the results of the performance quality of the employees of the Cooperative and UMKM Office in Jember, especially in the Institutional Sector, Business Development is good. Based on the results of research in each quality indicator obtained from the work that has been carried out in accordance with the performance and quality of performance that has been achieved by civil servants in the Department of Cooperatives and SMEs in Jember Regency in the Field of Institutional, Business Development. Based on the results of the study, indicators of quality at work obtained by every employee in the Institutional Field, Business Development is less than the target but is included in the good category and the appraiser has given a good rating on every employee in the Institutional Field, Business Development although not all tasks or quantity achieved in accordance with the target but most of the tasks carried out have been carried out with the acquisition of quality above 80 or in the category (GOOD).

The quality of performance, especially in the Institutional Sector, Business Development is very prominent so that assessors map the head of the department always gives the best ratings on employees in the Institutional Sector, Business Development so that the good name of the Institutional Sector, Business Development is maintained.

c. Time

Time is a process to determine the number of hours worked by people used or needed to complete a job within a certain time with the provisions of the time needed for employees to complete their duties. The work done must be in accordance with the time, 
and there is a measure of the level of performance ability of each employee of the State Civil Apparatus in the Office of Cooperatives and SMEs in Jember Regency. The performance carried out within the indicator must be carried out in accordance with the time. So the time needed is always seen from the time achieved to complete the work or task in order to achieve efficiency in the use of time. Based on the results of the study, indicators of working time were obtained less than the target. So that the evaluator gives an unfavorable response and gives suggestions for more appropriate use of time, it is because the employee feels the time set is still lacking in completing the work due to the level of difficulty of the work and some of the work must coordinate with other agencies.

\subsubsection{Rating ASN performance is measured through Employee Work Behavior}

Assessment of work behavior is a way of assessing work skills that are carried out through observations by the appraisal officials of the assessed civil servants. Assessment of work behavior can identify input from other Appraisal Officers at the same level in their respective work fields.

\section{Service orientation}

Service orientation is the attitude and work behavior of civil servants in providing the best service to be served, including among others, the community, superiors, coworkers, related work fields, and / or other agencies. The results of research on civil servants in the Field of Institutions, Business Development Cooperatives and SMEs in Jember Regency, especially in the Institutional Field, Business Development has a service orientation in the good category, as well as the implementation of services that have been carried out through work behavior that can also have very good performance.

\section{Discipline}

Discipline is the ability of employees to obey obligations and avoid prohibitions specified in statutory regulations and / or official regulations which if not obeyed or violated are disciplined. Based on the research results obtained by Rini employees included in both categories with good discipline or attitude. Most of the responses from other employees and assessors also gave good responses. However, in some disciplinary indicators need to be improved such as the enforcement of strict sanctions.

\section{Cooperation}

Collaboration is the willingness and ability of Jember Regency Cooperative and UMKM staff in the Institutional, Business Development sector to work with colleagues, superiors, subordinates. The results of research on this indicator are included in both categories because every employee's activities in the Institutional Field are always routine in meeting in carrying out the tasks and problems of the community with fellow colleagues, superiors, subordinates, in their work units and other agencies, other employees and assessors also provide good response. 


\section{Senior employee with a 5-year term with Ms. Rini.}

Judgment of Work Behavior towards Rini's mother is carried out by Mr. Yudo Minarto as an appraisal official for every Civil Servant in the Institutional Field, Business Development must be assessed according to the work behavior obtained. There are a number of monitoring tasks assessments that must be carried out by Mrs. Rini as a Civil Servant and will be assessed by Mr. Yudo through the first Work Behavior Elements, namely: (1) Service Orientation, service orientation that is obtained by Ms. Rini as a civil servant is 80 and gets value in the (Good) category. (2) The integrity obtained by Mrs. Rini is 80 and gets a score in the (Good) category. (3) The commitment obtained by Mrs. Rini is 81 and gets a score in the (Good) category. (4) Discipline obtained by Mrs. Rini is 81 and gets a score in the (Good) category. (5) The collaboration obtained by Ibu Rini is 80 and gets a score in the (Good) category. The results of the assessment of the five indicators received a total number of 402 with an average value of 80.40 with the category (Good) then the Work Behavior Results obtained at $80.40 \times 40 \%$ to 32.16 plus SKP results 53.88 so as to get the final value of Work Achievement is 86.04. So that Rini gets a score in the (Good) category.

\section{Middle employee with a 3-year work period for Ms. Yuli.}

The assessment of Work Behavior towards Ms. Yuli was carried out by Mr. Yudo Minarto as an appraisal official for every Civil Servant in the Institutional, Business Development Sector. There are a number of monitoring tasks assessments that must be carried out by Ms. Yuli as a Civil Servant and will be assessed by Mr. Yudo through the first Work Behavior Elements, namely: (1) Service Orientation, service orientation obtained by Mrs. Rini is 80 and gets a category (Good ). (2) Integrity obtained is 80 and received the category (Good). (3) Commitments obtained are 80 and received the category (Good). (4) Discipline obtained is 80 and gets the category (Good). (5) Collaboration obtained is 80 and received the category (Good). The results of the assessment of the five indicators get a total of 400 with an average value of 80.00 with the category (Good) then the Work Behavior Results can be valued at $80.00 \times 40 \%$ to 32.00 plus SKP results 54.18 so that it gets a value the final work achievement worth 86.18 is categorized (good).

\section{Junior employee with a 2-year term of service towards Mr. Gustaf.}

The assessment of Work Behavior towards Mr. Gustaf is carried out by Mr. Yudo Minarto as an appraisal official for every Civil Servant in the Institutional, Business Development Sector. There are several monitoring tasks assessments that must be carried out by Mr. Gustaf as a Civil Servant and will be assessed by Mr. Yudo through the first Work Behavior Elements, namely: (1) Service Orientation, service orientation obtained by Mrs. Rini is 86 and gets a category (Good ). (2) Integrity obtained is 82 and received a category (Good). (3) The commitment obtained is 82 and gets the category (Good). (4) Discipline obtained is 80 and gets the category (Good). (5) Collaboration obtained is 81 and received a category (Good). The results of the assessment of the five indicators get a total of 411 with an average value of 82.20 with the category (Good) then the Work 
Behavior Results that can be valued at $82.20 \times 40 \%$ to 32.88 plus the SKP results 52.00 so that it gets a value the end of the Work Achievement worth 84.88 is categorized (Good).

\subsection{Individual Performance Appraisal in the Institutional Sector, Business Development in the Cooperative and UMKM Office of Jember Regency}

Performance appraisal of the State Civil Apparatus is a way of assessing employees through the Employee Work Targets and work behavior carried out through observations by the appraisal officials of the assessed Civil Servants, Performance appraisal of the State Civil Apparatus uses a way of looking at Employee Work Targets and work behavior can consider input from Officials Other equal appraisers in the area of Business Development Institutions.

Based on the statement, work performance is seen from the employee's work objectives (SKP) and employee work behavior. Performance appraisal at the Department of Cooperatives in Jember Regency there are two ways of appraisal, the first appraisal is through employee work objectives (SKP), the second is assessing employee behavior, performance appraisal according to the appraiser, each employee must make an SKP position assignment and what he must do in accordance with the target that he must achieve. Each employee must carry out office duties that have a period of 10-11 months. If the assignment is carried out according to the target, then it will get good grades.

When conducting research in the Institutional Field, Business Development of one employee who is not on time, it can increase the value of the effectiveness of employee coordination. In fact, when the researcher conducted observations and interviews for the evaluator, the SKP (Employee Work Target) value that could be accepted by one of the employees, the assessor still gave a good grade. But the fact is that not all employees included in the SKP (Employee Work Goals) are well approved. After the researchers let go, the reason the appraisers did not negotiate employees who opposed the discipline of time, even always giving a good rating to one of the employees, caused a debate about the Institutional and Business Development fields, besides that safety would also provide a great opportunity to get an award. After the researcher makes a decision related to the research, the supervisor's party or the Head of Office does not reveal the actual event, because actually there is still one of the employees who comes late and discusses the value of discipline included in the employee work relationship. Researchers also like the participation between appraisers and employees in giving value, because the appraiser and the employee also have the goal of keeping the employee who is kept safe and not reducing his benefits. If the employee gets a bad grade, the employee will not get a prize (award), so the other way around with the appraiser. If the employee who is expelled gets a good grade, then the protection unit's good name and reputation will remain good. In addition, the Office of Cooperatives and MSMEs in Jember Regency in terms of job benefits does not differentiate between ten years, 3 years and 2 years.

The impact of the evaluator gives a good value to one of the employees who is late, will affect the performance of employees and will likely interfere with other employees. If that is not a problem, it could be that other employees will do the same. If 
this continues, the impact will affect the performance targets of the Jember Regency Cooperative and UMKM offices. Therefore, if there is one employee who violates, the appraiser should immediately reprimand and discuss this matter with his employees carefully or the appraiser immediately asks for advice directly from the Head of the Cooperative Office, so that the late behavior is not repeated again.

The SKP assessment requirements and work behavior are not just administrative requirements. However, the value obtained by each employee, makes a reflection of himself in accordance with work behavior. The SKP assessment requirements and work behavior aim to make employees aware of time discipline. This time discipline assessment is related to the theory of Hasibuan (2008: 94) which states that performance is a result of work achieved by a person in carrying out the tasks assigned to him, and is based on skills of experience and sincerity as well as time. The higher the quality of work and time discipline, the greater the performance for employees in the Institutional Sector, Business Development. So it can be said that performance is the embodiment of work carried out by employees as a basis for assessment in the Institutional, Business Development Division of the Cooperative Office and SMEs in Jember Regency. 
Performance Assessment of Country Civil Apparatures in the Institution of Business

Development in Cooperative and Msme Business Jember District

\section{CLOSING \\ 5.1 Conclusions}

Performance Appraisal of the State Civil Apparatus in the Cooperative and UMKM Office of Jember Regency conducts an assessment through Employee Work Targets and employee work behavior. Performance Appraisal through Employee Work Targets and employee work behavior is a good change to improve the work performance of employees of the State Civil Apparatus in the Cooperative Office especially in the Institutional, Business Development Sector. Assessment using employee work goals and employee work behavior will more easily determine the performance capabilities of the State Civil Apparatus employees. This assessment can see the ability to carry out their duties and responsibilities in accordance with the results of good work performance values. The improvement of this regulation also has a good impact on improving the performance of government agencies, especially in the Field of Institutions, Business Development in the Cooperative Office and SMEs in Jember Regency. Through a good rating system, it will produce good performance as well. The better the performance of employees, will certainly have a good impact on a government agency. Clear targets and objectives in the SKP and the ASN Law will have a good impact on improving the work performance of employees which directly impacts both the performance of their institutions.

\subsection{Suggestions}

1. For the Head of the Cooperative and MSME Office in Jember Regency to continue to improve their performance and directly monitor their employees so that the assessment is in accordance with applicable procedures.

2. For employees in the Cooperative and MSME Office of Jember Regency to continue to improve their performance and services that reflect the Community Service Servants. 
Page 759-777. ISBN: 978-602-6 988-75-1

Web Jurnal Online: jurnal.unmuhjember.ac.id

By: Laras Dwi Yunianingsih; Ria Angin

Performance Assessment of Country Civil Apparatures in the Institution of Business

Development in Cooperative and Msme Business Jember District

\section{BIBLIOGRAPHY}

\section{Book Source:}

Bernadin, H. J. 2007. Human Resource Management: An Approach Exponential. 4th ed. New York: McGraw-Hill Irwin, 253-277.

Dessler, G. 2003 Human Resource Management. Volume 2. Ninth Edition. Jakarta: Gramedia Group PT Index.

Handoko, Hani 2010. Personnel \& Human Resources Management, Second Edition, BPFE UGM Yogyakarta.

Hasibuan, M. S. P. 2006. Human Resource Management. Revised Edition. Jakarta: Bumi Akasara.

Hasibuan, Malayu. 2012. Human Resource Management. Jakarta: PT Bumi. Script

Moenir, A. S. 1995. Management of Indonesian Public Services. Jakarta: Earth Literacy.

Mangkunegara, A.Anwar.P.2011 Human Resource Management, Youth Rosdakarya, Bandung.

Mangkunegara, Anwar Prabu. 2002. Human Resource Management.

Bandung: Teen Rosdakarya.

\section{Journal Source:}

Nur Afni.2019. Performance of the State Civil Apparatus Office of the Transmigration and Manpower SME Cooperatives (Case Study of the adoption of Regent Regulation No.18 of 2011). Rokahulu: Government Science Department.

Roosje Kalangi.2015. Human Resource Development and Performance of the State Civil Apparatus in the Sangihe Islands District, Nort Sulawesi Province. Sangihe Islands: Department of Government Science.

Sisila Koda.2017. Efforts to Improve the Performance of the State Civil Apparatus (Daru Health Center Study, North Kao District. North Halmahera: Department of Government Science.

Taupik Rahman.2017. Performance of State Civil Apparatus in Public Services. Paser: Department of Government Science.

\section{Other Documents:}

Regent Regulation Number 43 of 2016 concerning Kedududkan, Organizational Structure, Duties and Functions and Work Procedures of the Cooperative and MSME Office of Jember Regency

Job Target Employees in the Cooperative and MSME Office in Jember Regency ASN Law Number 5 Year 2014 Regarding State Civil Apparatus. 